\title{
Article \\ Allosteric Modulation of GSK-3 $\beta$ as a New Therapeutic Approach in Limb Girdle Muscular Dystrophy R1 Calpain 3-Related
}

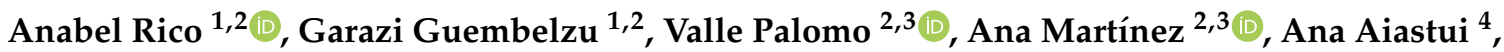 \\ Leire Casas-Fraile ${ }^{1,2}\left(\mathbb{D}\right.$, Andrea Valls ${ }^{1,2}{ }^{\mathbb{D}}$, Adolfo López de Munain ${ }^{1,2,5,6}$ and Amets Sáenz ${ }^{1,2,5, *(\mathbb{D})}$ \\ 1 Biodonostia Health Research Institute, Neurosciences Area, 20014 San Sebastian, Spain; \\ anabelr6@gmail.com (A.R.); garazi13@gmail.com (G.G.); leire.casas@kuleuven.be (L.C.-F.); \\ andrea.valls@biodonostia.org (A.V.); adolfojose.lopezdemunainarregui@osakidetza.eus (A.L.d.M.) \\ 2 Spanish Ministry of Economy \& Competitiveness, Carlos III Health Institute, CIBERNED, 28031 Madrid, \\ Spain; vpalomo@cib.csic.es (V.P.); ana.martinez@csic.es (A.M.) \\ 3 Centro de Investigaciones Biológicas Margarita Salas CSIC, 28040 Madrid, Spain \\ 4 Biodonostia Health Research Institute, Cell Culture and Histology Platform, 20014 San Sebastian, Spain; \\ ana.aiastui@biodonostia.org \\ 5 Osakidetza Basque Health Service, Donostialdea Integrated Health Organisation, Department of Neurology, \\ 20014 San Sebastian, Spain \\ 6 Department of Neurosciences, University of the Basque Country UPV-EHU, 20014 San Sebastian, Spain \\ * Correspondence: amets.saenzpena@osakidetza.eus

Citation: Rico, A.; Guembelzu, G.; Palomo, V.; Martínez, A.; Aiastui, A.; Casas-Fraile, L.; Valls, A.; López de Munain, A.; Sáenz, A. Allosteric Modulation of GSK-3 $\beta$ as a New Therapeutic Approach in Limb Girdle Muscular Dystrophy R1 Calpain 3-Related. Int. J. Mol. Sci. 2021, 22, 7367. https://doi.org/10.3390/ ijms22147367

Academic Editor:

Silvia Ortega-Gutiérrez

Received: 26 May 2021

Accepted: 6 July 2021

Published: 8 July 2021

Publisher's Note: MDPI stays neutral with regard to jurisdictional claims in published maps and institutional affiliations.

Copyright: (c) 2021 by the authors. Licensee MDPI, Basel, Switzerland. This article is an open access article distributed under the terms and conditions of the Creative Commons Attribution (CC BY) license (https:// creativecommons.org/licenses/by/ $4.0 /)$.
Abstract: Limb-girdle muscular dystrophy R1 calpain 3-related (LGMDR1) is an autosomal recessive muscular dystrophy produced by mutations in the CAPN3 gene. It is a rare disease and there is no cure or treatment for the disease while the pathophysiological mechanism by which the absence of calpain 3 provokes the dystrophy in muscles is not clear. However, key proteins implicated in Wnt and mTOR signaling pathways, which regulate muscle homeostasis, showed a considerable reduction in their expression and in their phosphorylation in LGMDR1 patients' muscles. Finally, the administration of tideglusib and VP0.7, ATP non-competitive inhibitors of glycogen synthase kinase $3 \beta$ (GSK-3 $\beta$ ), restore the expression and phosphorylation of these proteins in LGMDR1 cells, opening the possibility of their use as therapeutic options.

Keywords: LGMDR1; limb-girdle muscular dystrophy; CAPN3; tideglusib; VP0.7; GSK-3ß; Wnt; mTOR

\section{Introduction}

Limb-girdle muscular dystrophy R1 calpain 3-related (LGMDR1) is an autosomal recessive muscular dystrophy produced by mutations in the CAPN3 gene that causes progressive degeneration of the proximal muscles of the pelvic and shoulder girdle. The disease begins in the second decade of life and muscle degeneration leads to muscle weakness and atrophy that confines patients to a wheelchair in around 20 years of disease progression [1,2]. Subsequently, as muscle degeneration progresses, it becomes a highly disabling disease that prevents patients from performing simple daily tasks. Unfortunately, to date, there is no therapy that cures or even slows down the progression of muscle fiber degeneration.

Calpain 3 is a muscle-specific protease that may participate in several functions, such as muscle contraction due to its link to titin [3-7], cell membrane homeostasis [8,9] and the regulation of $\mathrm{Ca}^{2+}$ flow between the sarcoplasmic reticulum/cytoplasm [10].

Balanced homeostasis between the synthesis and degradation of proteins in the muscle fiber is key to maintain the muscle and thus to avoid muscle atrophy and weakness [11]. For that purpose, there are certain signaling pathways, such as the Akt/mTOR or the Wnt signaling pathways, which stimulate protein synthesis, myofiber growth and inhibit protein 
degradation [12]. They also participate in differentiation during muscle development and in the regeneration of muscle fiber in adults [13].

When the Wnt signaling pathway is active, Wnt ligands induce the inactivation of GSK-3 $\beta$ preventing $\beta$-catenin phosphorylation, allowing its accumulation in the cytoplasm and translocating it to the nucleus. Then, $\beta$-catenin binds to T-Cell Factor/Lymphoid Enhancer Factor (TCF/LEF) and activates downstream target genes [14,15]. On the contrary, when the Wnt signaling pathway is inactive, GSK- $3 \beta$ is activated. It phosphorylates $\beta$ catenin so that it is subsequently degraded [16]. GSK-3 $\beta$ is a constitutively active kinase that controls numerous aspects of cell physiology, such as proliferation, metabolism and apoptosis [17-20].

Among the drugs that inhibit GSK-3 $\beta$, lithium is a widely used drug. Due to its activator role in the Wnt signaling pathway, certain studies showed beneficial results in vitro [21-24]. Additionally, in vivo studies have shown protective effects in a slowly progressive spinal muscle atrophy mouse model [25] and improvement in muscle size and strength in an LGMD1D preclinical mouse model [26].

Among the molecules that are able to inhibit GSK-3, the ATP-competitive ones have often presented important adverse side effects in long-term treatments. On the other hand, those that inhibit GSK-3 $\beta$ in a non-competitive or allosteric way are more selective [27-29], with the thiadiazolidinone (TDZD) family being the first ATP non-competitive inhibitor of GSK- $3 \beta$ reported. Since then, various highly selective and allosteric analog drugs were synthesized, including tideglusib and VP0.7 [27,30].

Tideglusib is an irreversible drug designed for the treatment of Alzheimer's disease and whose safety for human treatment has been demonstrated [31]. VP0.7, on the other hand, is a drug that modulates the kinase allosterically [30]. Furthermore, it has been reported that a VP0.7 and a second structural related derivative correct delayed myogenesis in myoblasts from patients with type 1 congenital myotonic dystrophy (CDM1) [27].

The pathophysiological mechanism by which the absence of calpain 3 provokes the dystrophy in muscles is not clear. Loss of calpain 3 leads to the deregulation of the expression of several genes/proteins and to abnormal sarcomere formation in the muscles $[24,32,33]$. Costameres are complexes that may rule the sarcomere assembly and stabilization [34-36]. They enable the adhesion between the sarcomere in the muscle and the extracellular matrix and this linkage is partially mediated by integrins $[37,38]$. In LGMDR1 myotubes, the physiologically required replacement of the integrin $\beta 1 D$ isoform is disturbed and may be the cause of incorrect costamere assembly. Moreover, a crosstalk was identified between integrin and Wnt signaling pathways [24]. Currently, there is no cure or treatment for limb girdle muscular dystrophy R1 calpain 3-related.

In this work, we report expression alterations in proteins implicated in signaling pathways that regulate muscle homeostasis, such as Wnt and mTOR pathways. LGMDR1 patients' muscles showed a severe reduction in the expression of the proteins involved in these pathways. Finally, our study showed that tideglusib and VP0.7, ATP non-competitive GSK-3 $\beta$ inhibitors, restore the expression and phosphorylation of key proteins in Wnt and mTOR pathways, opening up the possibility of their use as therapeutic options in LGMDR1.

\section{Results}

\subsection{The Wnt/B-Catenin Pathway Is Altered in the Muscle of LGMDR1 Patients}

Previous studies had described the overexpression of FRZB, a Wnt1, 5a, 8 and 9a antagonist, in the muscle of LGMDR1 patients [24]. Due to the excessive inhibition of this pathway, the expression of some proteins participating in the Wnt pathway has been analyzed.

The levels of GSK-3 $\beta$ and total $\beta$-catenin do not show differences between patients and controls, as well as p-GSK-3 $\beta$ (Ser9). On the contrary, the active form of $\beta$-catenin showed a drastic decrease of the protein in patients, except in a benign patient (B0926). This reduction was not observed in the pseudo-asymptomatic cases (05 and 07-109). These pseudo-asymptomatic cases were 13- and 10-year-old patients who only presented 
hyperCKemia and eosinophilia. In most of the analyzed proteins, an increase in expression (not statistically significant, $n=2$ ) has been observed in pseudo-asymptomatic cases with respect to the controls (Figure 1).
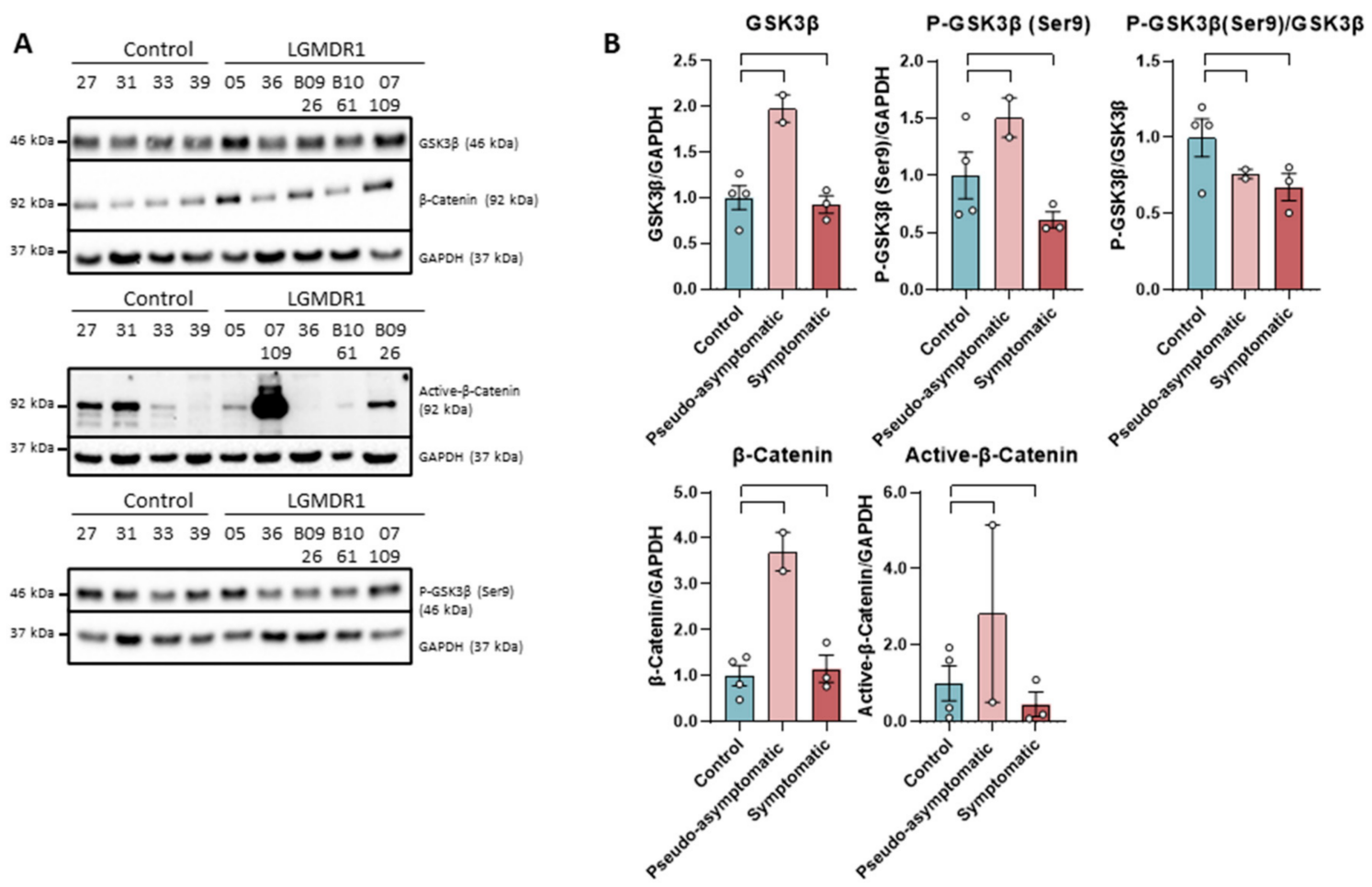

Figure 1. Western blot (A) and densitometry analysis (B) of Wnt signaling pathway proteins in samples from muscles of LGMDR1 and controls: total GSK-3 $\beta$, P-GSK-3 $\beta$ (Ser9), P-GSK-3 $\beta /$ GSK-3 $\beta, \beta$-catenin and Active $\beta$-catenin. Control samples $(n=4)$, symptomatic patients $(n=3)$ and pseudo-asymptomatic patients $(n=2)(05$ and $07-109)$. All error bars represent standard error of the mean (SEM). Each circle represents a sample. Loading control: GAPDH.

\subsection{Reduction in the Activation of the mTOR Pathway in the Muscle of LGMDR1 Patients}

The expression of mTOR as well as its phosphorylated form in Ser2448 are severely reduced in the muscle of LGMDR1 patients. The decrease of both forms can be observed in pseudo-asymptomatic and symptomatic patients (Figure 2). 
A

Control LGMDR1

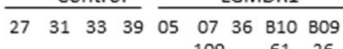

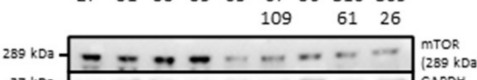

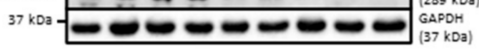

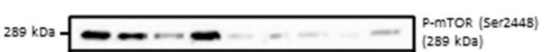

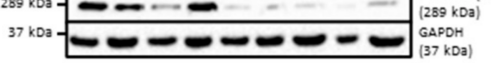

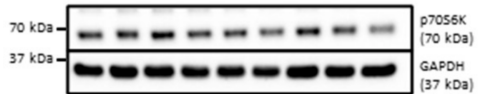

Control

LGMDR1

$\begin{array}{llllllllll}42 & 27 & 31 & 33 & 38 & 05 & 09 & 36 & 97\end{array}$
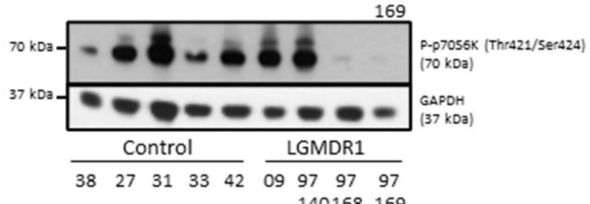

$70 \mathrm{kDa}-140168169$

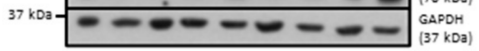
Control

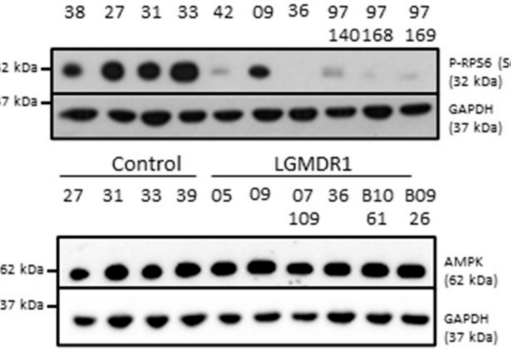

B

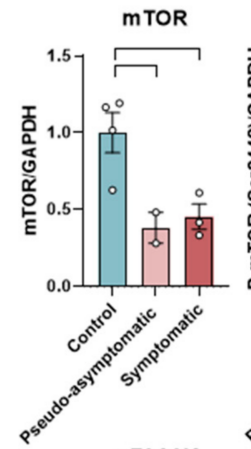

p70s6K
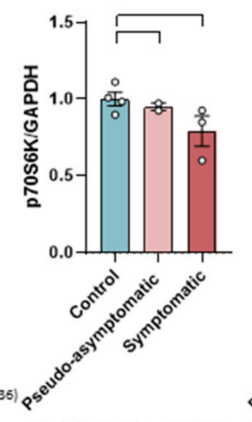

0.0

P-RPS6 (Ser235/Ser236)

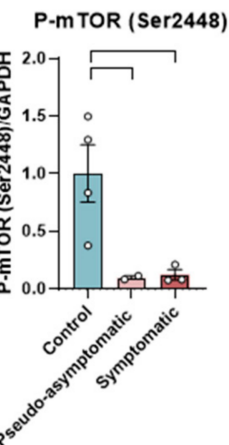

P-m TOR (Ser2448)/m TOR

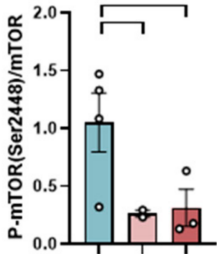

P-p70S6K (Thr389) P-p70S6K (Thr421/Ser424) P-p70S6K (Thr421/Ser424)/p70S6K
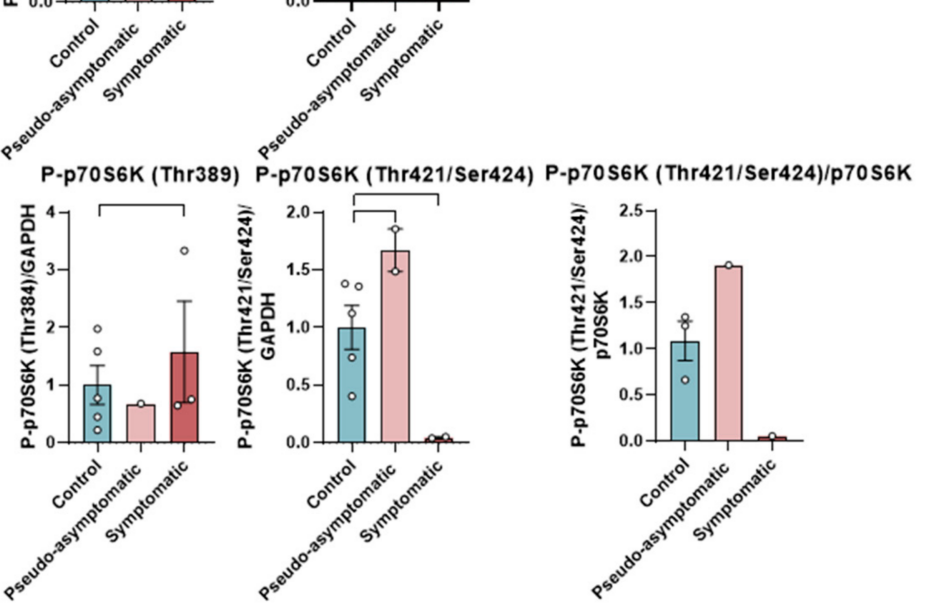

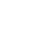
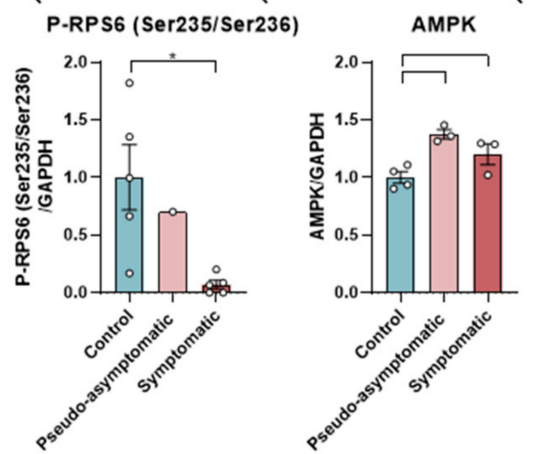

Figure 2. Western blot (A) and densitometry analysis (B) mTOR signaling pathway proteins in samples from muscles of LGMR1 and controls: mTOR, P-mTOR (Ser2448), mTOR/P-mTOR (Ser2448), p70S6K, P-p70S6K (Thr389), P-p70S6K (Thr421/Ser424), p70S6K/P-p70S6K (Thr421/Ser424), P-RPS6 (Ser235/Ser236) and AMPK. P-RPS6 is statistically significant in symptomatic patients $(p=0.0159) .05,09$ and 07-109: pseudo-asymptomatic patients. Control samples $(n=4)$ for mTOR, P-mTOR, p70S6K and AMPK and $(n=5)$ for P-p70S6K -Thr389 and Thr421/Ser424- and P-RPS6. Symptomatic patients $(n=3)$ for mTOR, P-mTOR, p70S6K, P-p70S6K (Thr389), P-RPS6 and AMPK, $(n=2)$ for P-p70S6K (Thr421/Ser424) and $(n=1)$ for p70S6K/P-p70S6K (Thr421/Ser424). Pseudo-asymptomatic patients $(n=3)$ for AMPK, $(n=2)$ for mTOR, P-mTOR, p70S6K and P-p70S6K (Thr421/Ser424) and $(n=1)$ for P-p70S6K (Thr389), P-RPS6. All error bars represent standard error of the mean (SEM). *: Statistically significant. Each circle represents a sample. Loading control: GAPDH.

Subsequently, the expression of kinases downstream of this pathway was analyzed. p70S6K is a kinase participating in the mTOR pathway that is activated by sequential phosphorylations [39-41]. Our results show that the levels of total protein p70S6K and its phosphorylated form at residue Thr389 in controls and patients are similar. In contrast, symptomatic patients showed a greatly decreased level of phosphorylation at the Thr421/Thr424 residues (Figure 2). Downstream, the kinase p70S6K catalyzes the phosphorylation of ribosomal protein S6 (RPS6), whose phosphorylation correlates with high levels of protein translation and synthesis [40,42]. When analyzing mTOR, P-mTOR (Ser2448) and PRPS6 (Ser235/Ser236), a statistically significant decrease was found in the muscle of LGMDR1 patients when both subgroups were analyzed together $(p=0.00159 ; p=0.00159$ and $p=0.0303$, respectively, data not shown). 
On the other hand, as it is known that AMPK kinase is an inhibitor of the mTOR pathway [43-45], it was analyzed in the muscle of the patients, and an increase in the amount of this kinase was observed in the group of patients $(p=0.0381)$ (Figure 2).

As a summary, a schematic representation of the altered proteins in Wnt and mTOR pathways in LGMDR1 muscle are shown (Figure 3).

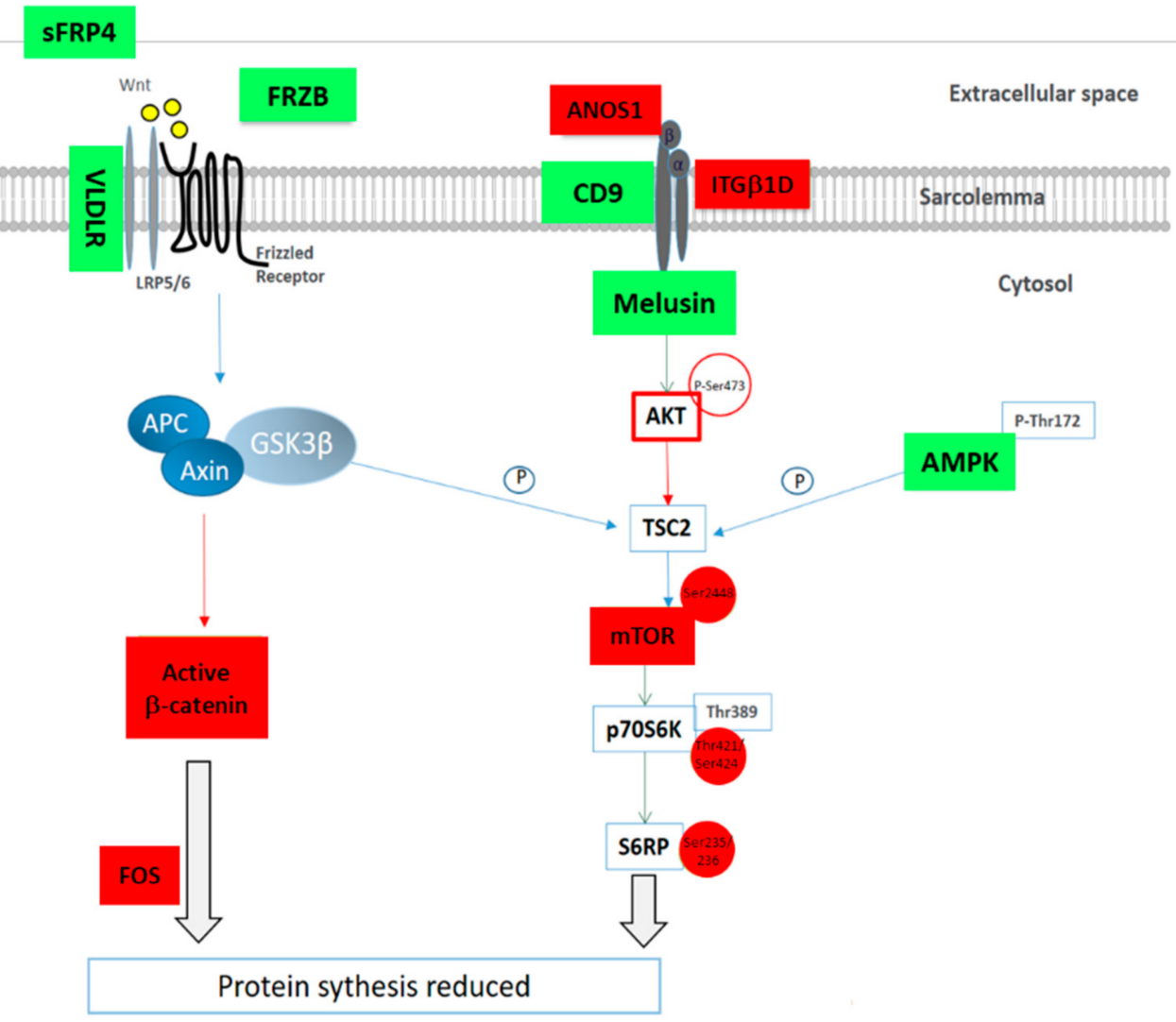

Figure 3. Schematic representation of the altered protein expression or phosphorylations in Wnt and mTOR signaling pathways in LGMDR1 muscle. Green: Upregulated expression or phosphorylation in LGMDR1. Red: Downregulated expression in LGMDR1.

\subsection{In Vitro Treatment with GSK-3ß Inhibitors: Tidelgusib, VP0.7 and Li}

Lithium and the small molecule drugs tideglusib and VP0.7 were used in this study. While lithium is a known and widely used GSK-3 inhibitor, its unwanted adverse effects entailed in clinical trials led us to the search of selective GSK-3 inhibitors with an optimal safety profile, including tideglusib and VP0.7. These drugs were administered in different cell types: primary myotubes, CD56- cells and skin fibroblasts. The effect on the response for the administered drugs was different depending on the cell type.

2.3.1. Activation of the Wnt Pathway in Human Myotubes and Recovery of Deregulated Gene Expression in LGMDR1 Patients

We proceeded to analyze the expression of GSK-3 $\beta$, as well as its downstream effect on the Wnt pathway in myotubes from controls and patients after drug administration. Inhibition by tideglusib and VP0.7 slightly increases the amount of total GSK-3 $\beta$ and its phosphorylation (Ser9) in patients. The activation of the Wnt pathway was confirmed by effective inhibition of GSK-3 $\beta$, since an increase in total $\beta$-catenin expression as well as active $\beta$-catenin was observed with tideglusib and VP0.7. As a control assay, lithium was administered, and an increase in active $\beta$-catenin was also verified (Figure 4A). 
A
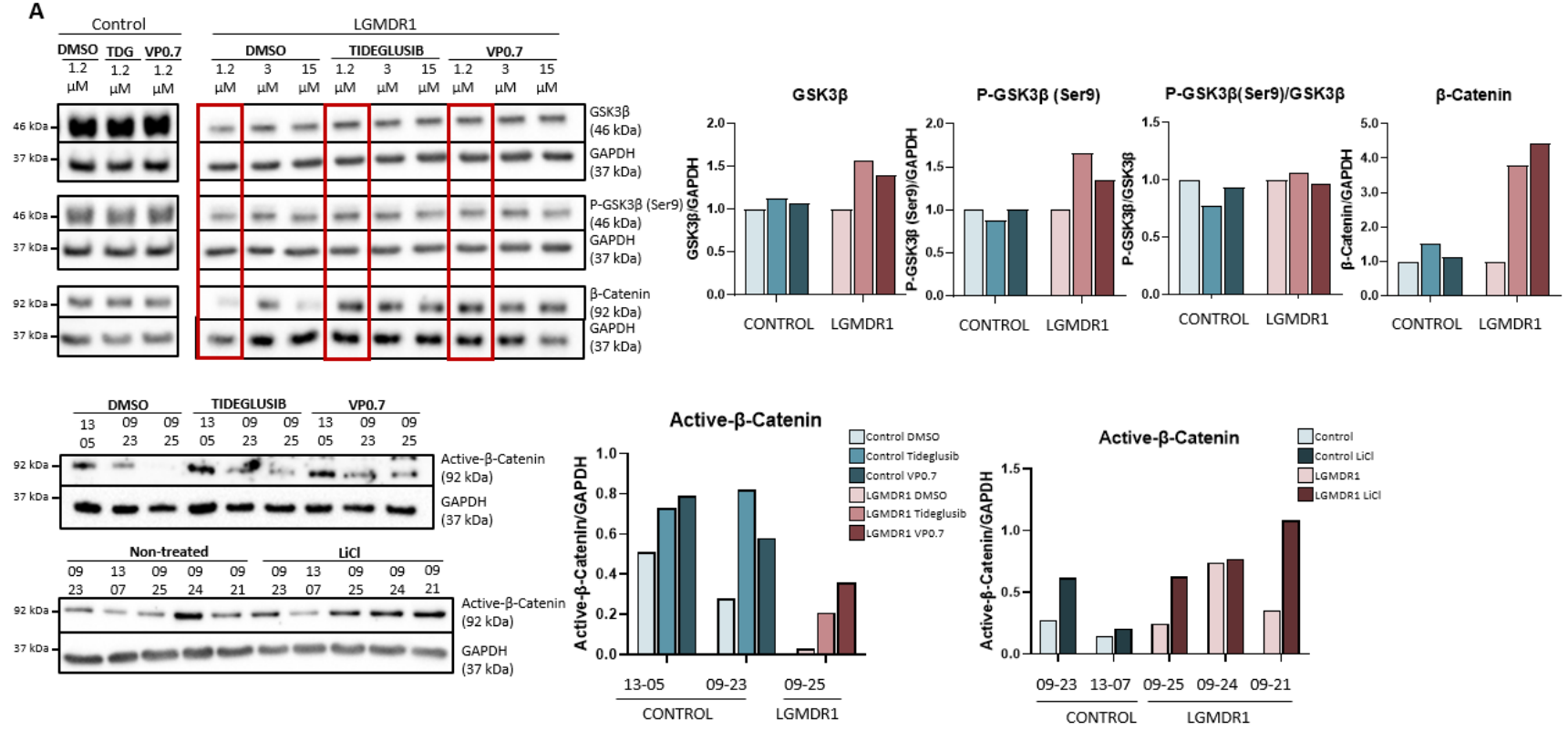

B

C

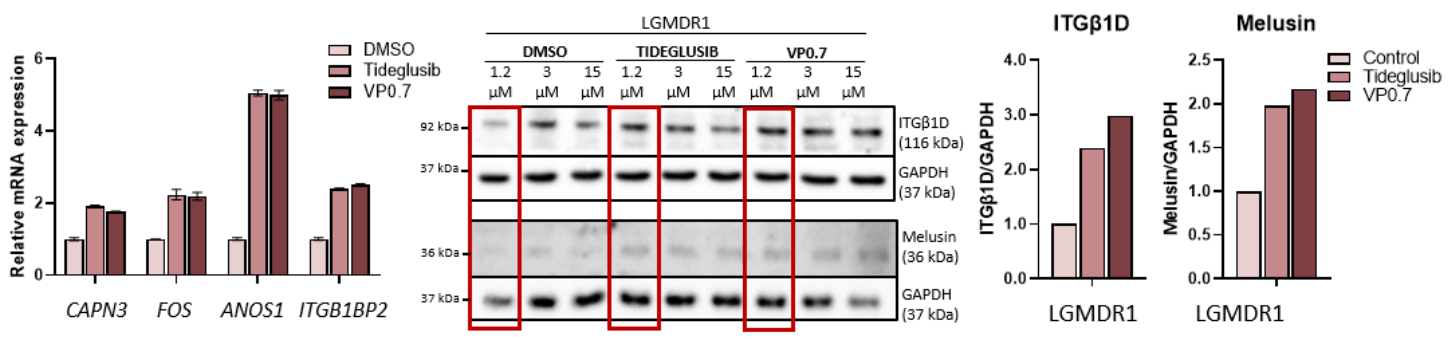

Figure 4. Activation of the Wnt pathway in human myotubes on day 8 of differentiation and after $48 \mathrm{~h}$ of treatment with Tideglusib and VP0.7 at three concentrations $(1.2,3.0$ and $15.0 \mu \mathrm{M})$ and $\mathrm{LiCl}$ in control $(n=1)$ and patient LGMDR1 ( $n=1)$. (A) Wnt signaling pathway activation: western blot of total GSK-3 $\beta$, P-GSK-3 $\beta$ (Ser9), P-GSK-3 $\beta /$ GSK-3 $\beta$, total $\beta$-catenin and active $\beta$-catenin. (B) Expression of CAPN3, FOS, ANOS1 and ITGB1BP2 genes in LGMDR1 myotubes $(n=1$ with technical triplicates). (C) Western blot of structural proteins: ITG $\beta 1 \mathrm{D}$ and melusin. In red, lowest concentration used in the LGMDR1 myotubes $(1.2 \mu \mathrm{M})$ for densitometry analysis.

On the other hand, in previous studies, we had already described that activating the Wnt pathway through the silencing of the FRZB gene or with treatment with lithium, the expression of some altered genes in the muscle of patients was recovered [24,46]. Thus, their expression was analyzed after administering tideglusib and VP0.7. The results showed a correlation with the effect generated by the $F R Z B$ gene silencing, that is, an increase in the expression of the CAPN3, FOS and ANOS1, and an increase in ITGB1BP2 was also observed (Figure 4B).

The expression of some of the structural proteins that are part of the costamere, whose expression is altered in LGMDR1 patients, was analyzed. After drug administration, an increase in integrin $\beta 1 \mathrm{D}$ and melusin was observed (Figure 4C).

\subsubsection{Activation of the Akt/mTOR Pathway in Myotubes from LGMDR1 Patients}

After administration of the drugs in the patient's myotubes, the amount of Akt expression and its phosphorylation (Ser473) increased slightly. For mTOR, hardly any changes were observed in total mTOR, but there was a substantial increase in phosphorylation of mTOR in two of its residues (Ser2448 and Ser2481) (Figure 5A). 

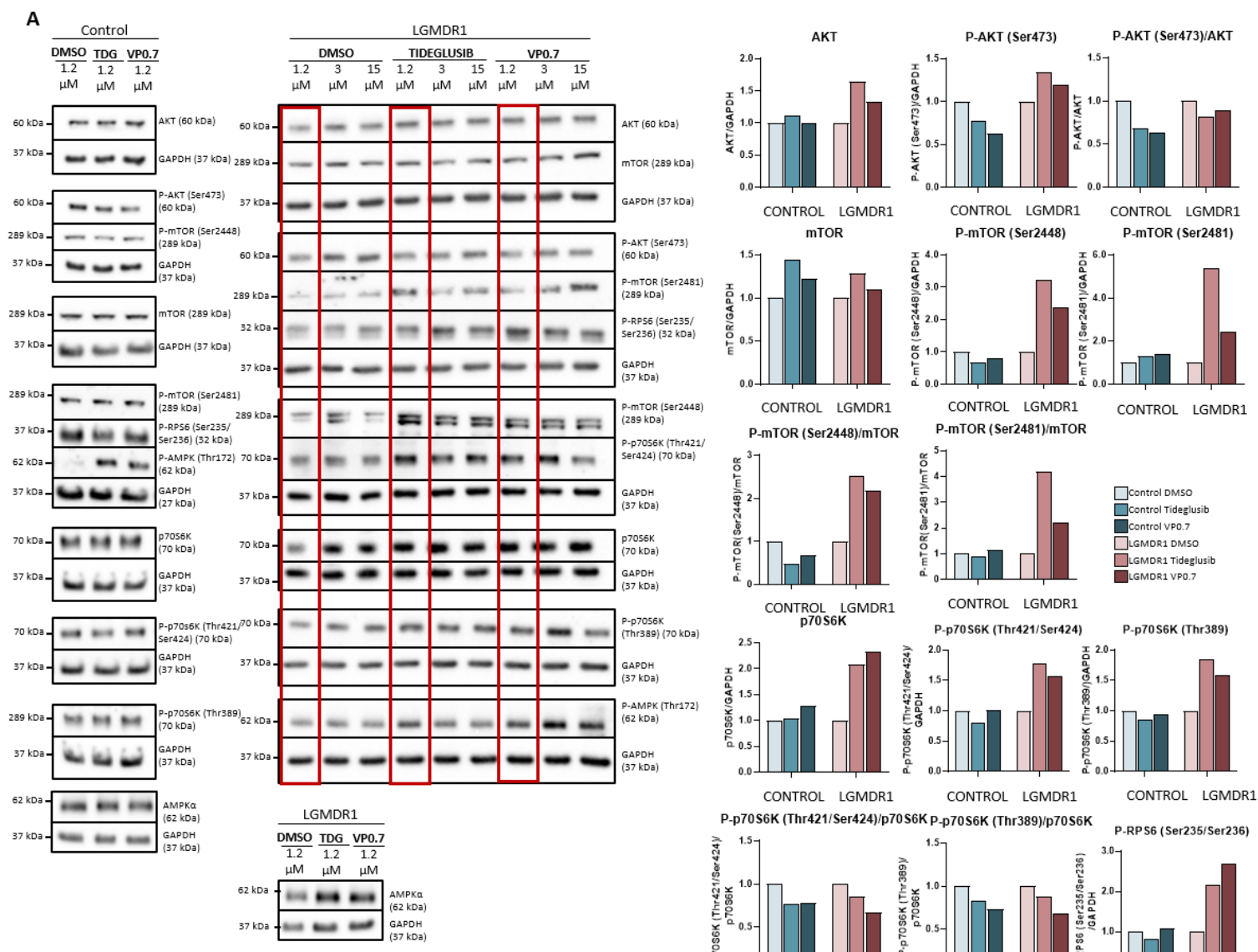

CONTROL LGMDR1 P-p70s6K (Thr421/Ser424) P.p70s6K (Thr389)
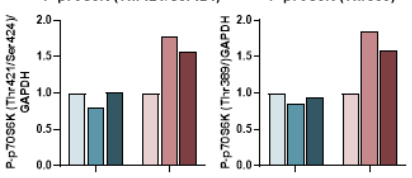

P-p70S6K (Thr421/Ser424)/p70S6K P-p70S6K (Thr389)/p70s6K
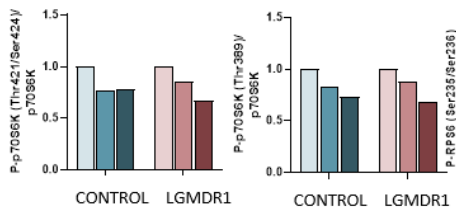

P.epse
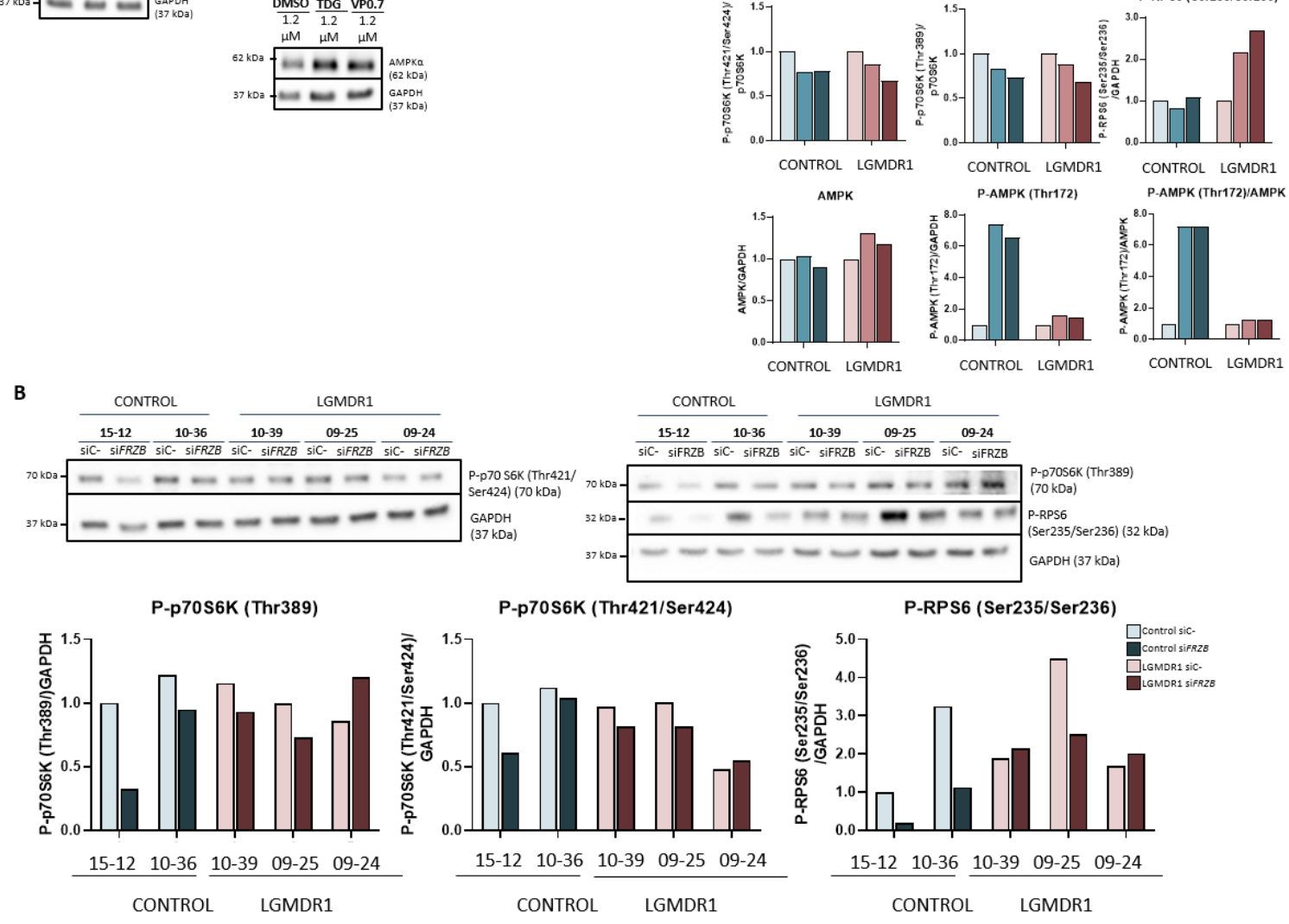

P.AMPK (Thr172)/AMPK

Figure 5. Activation of the Akt/mTOR pathway in human myotubes on day 8 of differentiation and after $48 \mathrm{~h}$ of treatment with tideglusib and VP0.7 at three concentrations $(1.2,3.0$ and $15.0 \mu \mathrm{M})$ in control $(n=1)$ and patient LGMDR1 $(n=1)$ : (A) western blot of AKT, P-AKT (Ser473), mTOR, P-mTOR (Ser2448 and Ser2481), p70S6K, P-p70S6K (Thr421/Ser424), P-p70S6K (Thr389), P-RPS6 (Ser235/Ser236) and P-AMPK (Thr172). (B) Effect of FRZB silencing on the mTOR pathway in controls' $(n=2)$ and LGMDR1 patients' $(n=3)$ myotubes. The red squares in the WB show the lowest concentration used in patients $(1.2 \mu \mathrm{M})$ for densitometry analysis. For the quantification of total AMPK $\alpha$ in LGMDR1 patient's myotubes, only the lowest dose was analyzed. 
Downstream of the mTOR pathway, the p70S6K and RPS6 proteins were analyzed. After administration of the drugs, the expression of total p70S6K, its phosphorylations (Thr421/Ser424 and Thr389), as well as the levels of phosphorylation of the RPS6 protein (Ser235/Ser236) increased in the patient's sample. In the control, the effect observed after the treatments is very mild (Figure $5 \mathrm{~A}$ ).

Finally, AMPK was analyzed after drug administration, and a slight increase in Thr172 residue phosphorylation was observed in the patient and a very marked increase in the control (Figure 5A).

On the other hand, given that in previous studies, the silencing of the FRZB gene had shown recovery in the expression of various altered genes in patients, we proceeded to analyze its possible effect beyond the Wnt pathway, specifically in the mTOR pathway. The silencing of the FRZB gene carried out in the myotubes did not show any effect on the regulation of the expression or on the phosphorylation of mTOR (data not shown). In addition, the activations of the downstream kinases of this pathway, P-p70S6K (Thr389), P-p70S6K (Thr421/Ser424) and P-RPS6 (Ser235/Ser236) were analyzed, but little effect or a slight decrease was observed (Figure $5 \mathrm{~B}$ ).

2.3.3. Absence of Activation of the Wnt Pathway in Fibroblasts and CD56- after Treatment with GSK-3 $\beta$ Inhibitor Drugs

In order to establish whether the effects previously observed after drug administration in myogenic cells (myoblasts differentiated to myotubes) occurred similarly in other cell types, we proceeded to study skin fibroblasts and CD56- cells obtained from muscle patients. We used two non-myogenic cell lines (one from non-muscular tissue and the other from muscular tissue, but not myogenic) to show that these drugs may not affect other cell lineages.

- Fibroblasts

Treatment with lithium in fibroblasts showed increased phosphorylation of GSK$3 \beta$ (Ser9), confirming that the treatment produces the desired kinase inhibition (Figure S1). Subsequently, the amount of total $\beta$-catenin and its active form were analyzed, as a downstream effect of the activation of the Wnt pathway, but no modification was detected in the expressed amount (Figure 6). Given that GSK-3 $\beta$ can interact with the mTOR pathway, we proceeded to analyze the effect that its inhibition could produce on its regulation. The analysis carried out does not show conclusive results that could suggest any modification in the expression of mTOR or in its phosphorylation (Ser2481). Finally, the phosphorylation of RP6S (Ser235/Ser236) did not show considerable variation after treatment with lithium (Figure 6). Thus, lithium treatment does not seem to activate the Wnt pathway or the mTOR pathway in fibroblasts.

Treatment with tideglusib and VP0.7 did not show an increase in the phosphorylation of GSK-3 $\beta$ (Ser9) (Figure 7). Since they are allosteric inhibitors, their inhibition could not be demonstrated by phosphorylation of Ser9 and it was considered that the inhibition of GSK-3 $\beta$ was taking place. $\beta$-catenin and its active form did not show an increase, indicating that the Wnt pathway is not activated in this cell type by means of tideglusib or VP0.7 (Figure 7). Finally, we analyzed the effect that the inhibition of GSK- $3 \beta$ could cause in the mTOR pathway. The phosphorylation of RPS6, only showed a slight increase with the treatment with VP0.7 (Figure 7). 


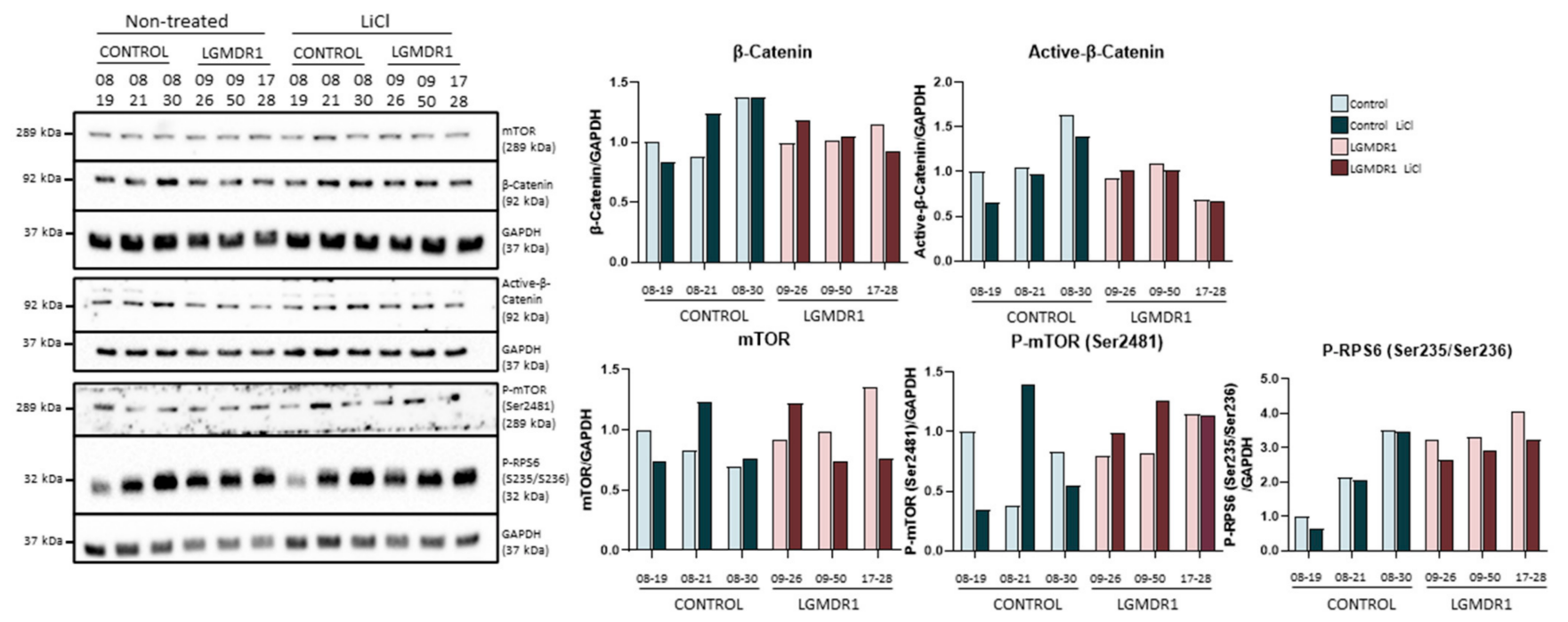

Figure 6. Analysis of fibroblasts of controls $(n=3)$ and LGMDR1 patients $(n=3)$ treated with LiCl.
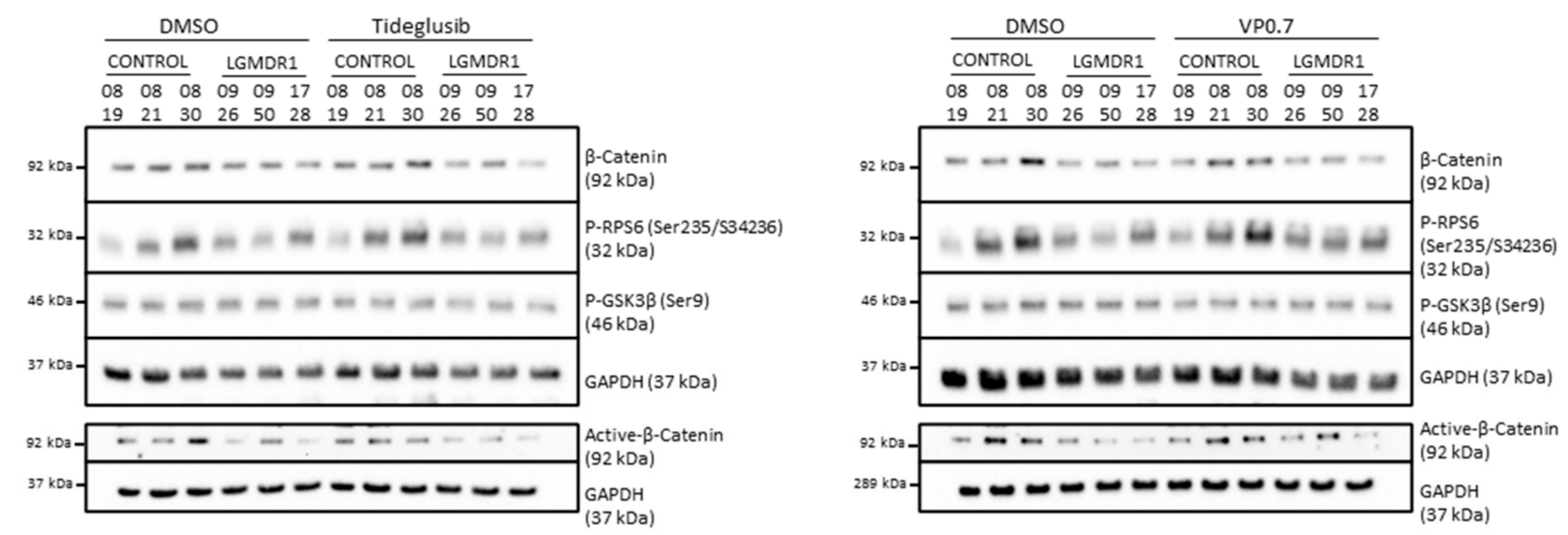

P.GSK33 (Ser9)

P-RPS6 (Ser235/Ser236)
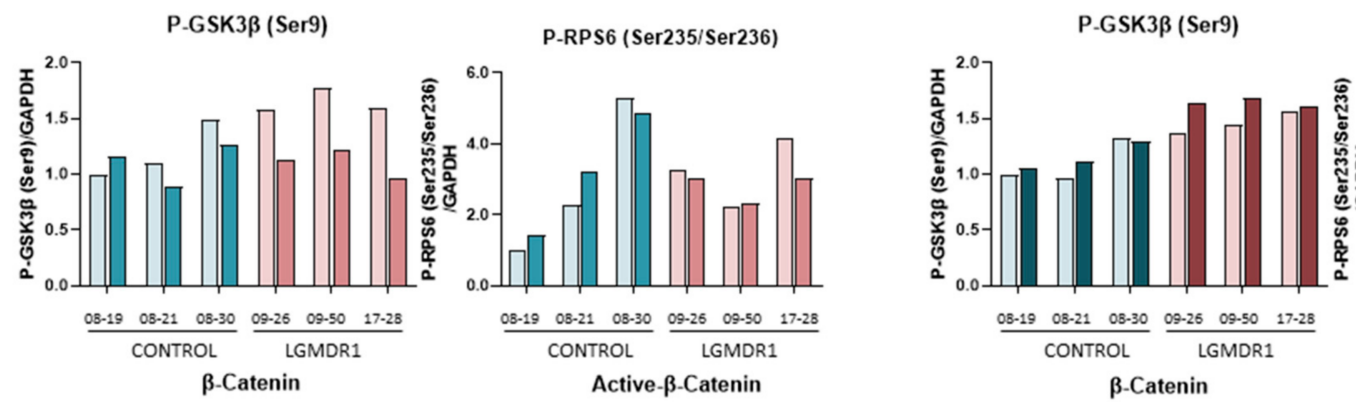

P-RPS6 (Ser235/Ser236)
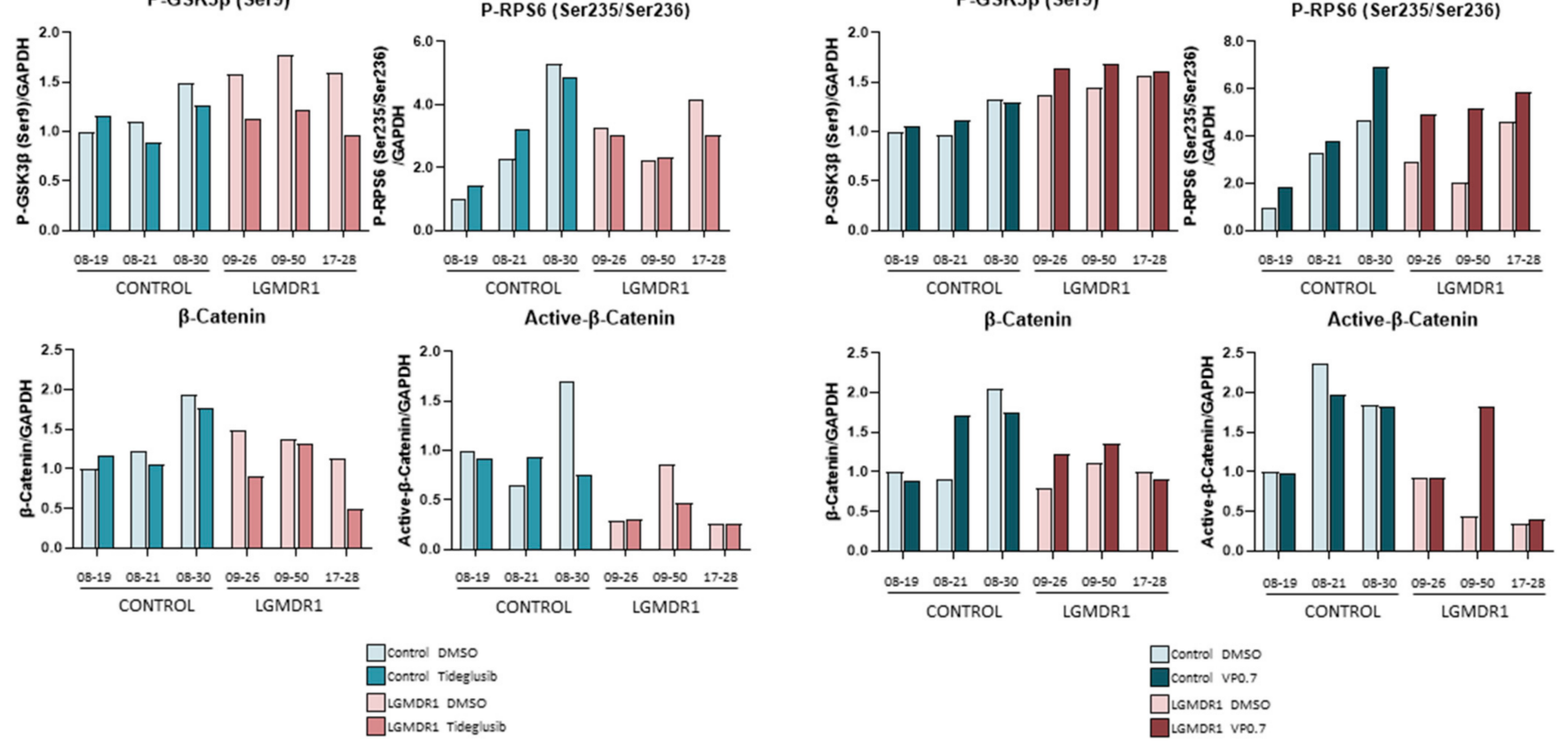

$\square_{\text {Control DMSO }}$
$\square_{\text {control vpo.7 }}$
$\square_{\text {LGMOR1 DMSO }}$
$\square_{\text {LGMOR1 VP0.7 }}$

Figure 7. Analysis of fibroblasts of controls $(n=3)$ and LGMDR1 patients $(n=3)$ treated with the GSK-3 inhibitors, tideglusib and VP0.7. 


\section{- CD56- cells}

As expected, the administration of lithium to CD56- cells showed that inhibition of GSK-3 $\beta$ through phosphorylation of the Ser9 residue occurred, since the amount of phosphorylated GSK- $3 \beta$ was increased (Figure S2). On the contrary, as observed in fibroblasts, no activation of the Wnt pathway was observed, since no difference was detected in the amount of active $\beta$-catenin (Figure 8A). The effect that this could have on the regulation of the mTOR pathway was also analyzed. However, no differences were observed downstream of this pathway due to lithium treatment (Figure 8A).
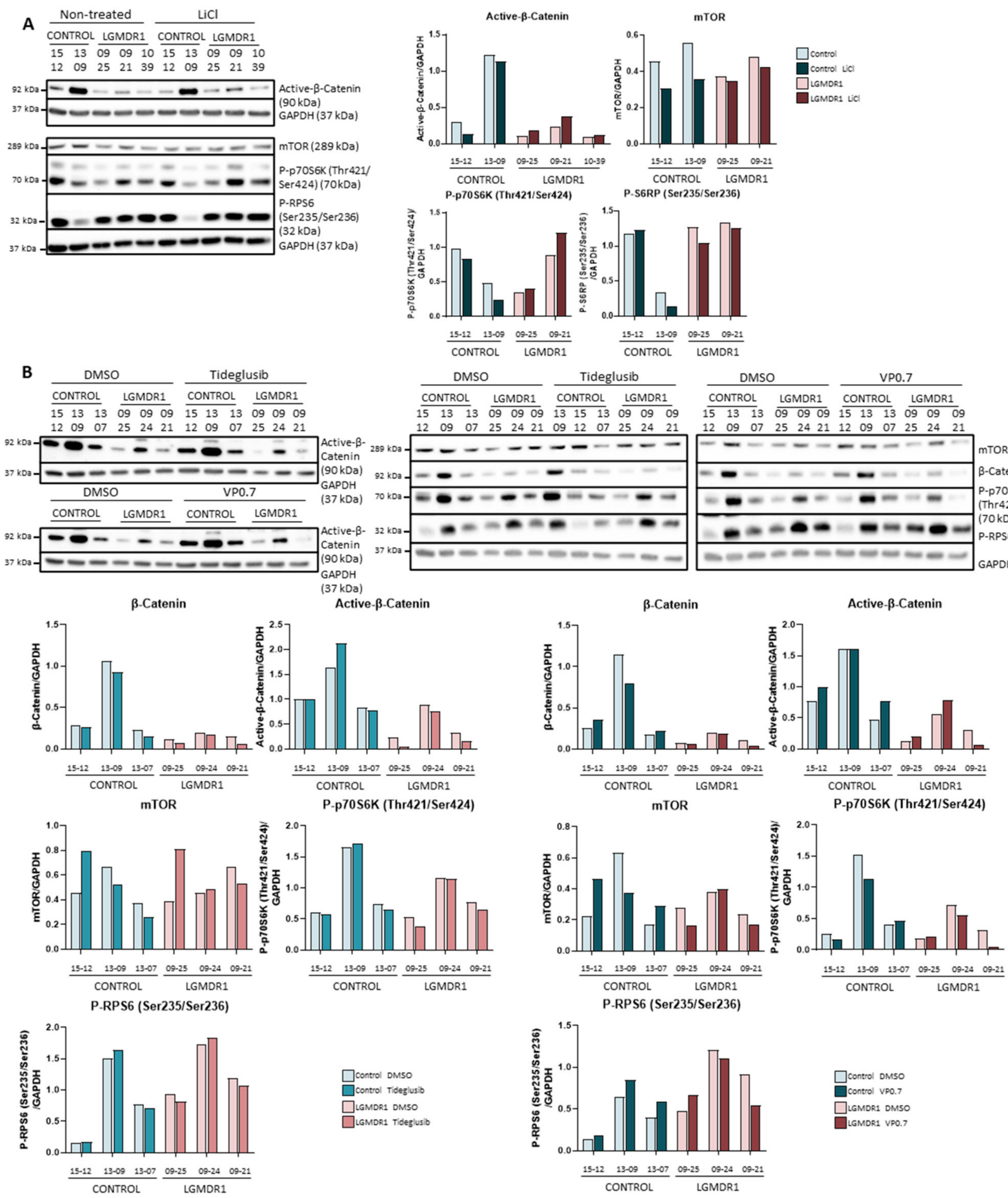

Figure 8. Analysis of CD56- cells treated with (A) $\mathrm{LiCl}$ (controls, $n=2$ and LGMDR1 patients, $n=3$ ) and (B) Tideglusib and VP0.7 (controls, $n=3$ and LGMDR1 patients, $n=3$ ). 
In the same manner, after treatment with tideglusib and VP0.7 in CD56- cells, no substantial alteration was observed in the amount of total $\beta$-catenin or in its active form (Figure 8A). Finally, the effect of this inhibition on the regulation of the mTOR pathway was analyzed, but no differences were observed in mTOR or in the phosphorylations of p70S6K and RPS6 (Figure 8A). Thus, the inhibition of GSK-3 $\beta$ by lithium, tideglusib or VP0.7 does not activate the Wnt or mTOR pathways in fibroblasts or CD56- cells (Figure 8B).

\section{Discussion}

It is known that as a consequence of the primary deficiency of a specific protein, there are alterations in different signaling pathways, as occurs in various forms of muscular dystrophy, where the signaling pathways of NF- $\mathrm{B}, \mathrm{MAPK}, \mathrm{PI} 3 \mathrm{~K} / \mathrm{Akt}$ and Cn/NFAT are altered [47]. It had previously been described that in the muscle of LGMDR1 patients, the primary deficiency of calpain 3 leads to an increase in NF- $k B$ [48] and dysregulation of gene and protein expression in the Wnt pathway [24,33].

In this work, two signaling pathways that regulate homeostasis in muscle fiber in LGMDR1 patients have been analyzed to establish, first, the pathways with the greatest impact on the pathophysiology of the disease, and second, the effect of the treatment with GSK-3 $\beta$ inhibitor drugs to regulate signaling pathways in patients.

\subsection{Alteration of the Wnt and Akt/mTOR Pathways}

Our study has allowed to establish that in the muscle of patients, there is a reduction of active $\beta$-catenin, which confirms that the Wnt pathway is altered. Additionally, Yalvac and colleagues [49] already showed in the CAPN3-KO model, after generating muscle damage, the altered expression of proteins that are involved in the Akt/mTOR signaling pathway. In muscle tissue from LGMDR1 patients, we also observed alterations in this signaling pathway, since they present a severe decrease in mTOR expression, its phosphorylation, as well as a reduction in the activation of downstream proteins of the pathway, which leads to the dysregulation of the growth of muscle fiber. This signaling pathway, like many others, receives different stimuli through growth factors, cellular energy levels, etc. that must be correctly integrated to stimulate protein synthesis and cell growth according to physiological requirements [50-52]. Although little is known about the way in which this integration for an adequate cellular response occurs, [53] demonstrated that TSC2, a critical upstream regulator of $\mathrm{mTOR}$, is responsible for the integration of the signal from the pathway of Wnt and the energy state of the cell.

On one hand, it has been shown that GSK-3 $\beta$ inhibits the mTOR pathway by phosphorylating TSC2, and thus, inhibits the downstream phosphorylation of S6K. Stimulation of the mTOR pathway by Wnt is independent of $\beta$-catenin-mediated transcription. The Wnt pathway bifurcates at the level of GSK-3 $\beta$ to regulate, on the one hand, translation by means of mTOR and, on the other hand, transcription by means of $\beta$-catenin [53]. Inhibition of GSK-3 $\beta$ has also been confirmed to stimulate the mTOR pathway in the heart during ischemia/reperfusion [54]. In our study, a significant reduction in the activity of the mTOR pathway was observed in muscle tissue from LGMDR1 patients due to the reduced amount of the mTOR protein and its phosphorylation.

Regarding the energy requirement of the cell, AMPK, AMP-activated protein kinase, is a cellular energy sensor that plays an important role in cell homeostasis [55]. Like GSK-3 $\beta$, AMPK can phosphorylate TSC2, which leads to a negative regulation of mTOR [49,56,57]. Thus, the reduced activity of the mTOR signaling pathway could also be due to the overexpression of AMPK observed in the muscle of the patients. However, the possible changes in AMPK phosphorylation could not be established due to the lack of detection of the phosphorylated protein in muscle samples.

Related to protein expression in pseudo-asymptomatic patients, we observed an increase in most of the analyzed proteins. This fact could be due to the expression profile derived from their young age, since pseudo-asymptomatic patients are 13 and 14 years old and it is known that age is a factor for regulating the expression of genes. Finally, 
the fact that the muscle samples from pseudo-asymptomatic patients present levels of phosphorylation of p70S6K and RPS6 similar to that of muscles of controls highlights the relevance of the activity of this pathway for the correct maintaining of the muscle function.

\subsection{Reactivation of the Wnt Pathway and Akt/mTOR Pathway}

With the administration of tideglusib and VP0.7 in myotubes, there is a total inhibition of GSK- $3 \beta$ that increases the amount of $\beta$-catenin and activates the mTOR pathway, confirming the participation of GSK- $3 \beta$ in both processes. Since the in vitro data shown here have been obtained from a patient and a control, these should be treated with caution. However, this finding supports the suitability of these drugs to be used as a treatment in LGMDR1, given that it could suggest that the undesirable side effects would be low.

Finally, thanks to the results obtained with the FRZB gene silencing, it has been established that the GSK-3 $\beta$ pool involved in the Wnt pathway (dependent on Wnt1, Wnt5a, Wnt8 and Wnt9a) does not participate in the regulation of the mTOR pathway. This is because Wnt does not affect the phosphorylation state of GSK-3 $\beta$ [58] and because not all GSK-3 $\beta$ molecules are located in the destruction complex [59].

\subsection{Lack of Effect of the Treatments on Fibroblasts and CD56-}

In the case of Tideglusib and VP0.7, their inhibition is not occurring by the phosphorylation of Ser9 and it cannot be confirmed this way. However, the effect of these drugs at the used concentrations have been confirmed in other experiments [60,61]. Moreover, we consider that, having observed an effect with these doses in myotubes, it was adequate for fibroblasts and CD56-.

Although the results seem promising, they should be treated with caution since they are results that were obtained in vitro and in a single patient. However, this work could help to shed some light on the knowledge of the underlying mechanisms of the LGMDR1 disease. The rescue of signaling pathways responsible of the synthesis of proteins that conform the costamere could help to improve its altered structure. Thus, it could also lead to a better functioning of the muscle fiber, improving the contraction and preventing the degeneration and, consequently, the death of the fiber.

In summary, we established the following relevant events that could orient towards possible therapeutic targets: (a) Wnt and mTOR signaling pathways are altered in the muscles of LGMDR1 patients. (b) Maintaining active the mTOR pathway, pseudo-asymptomatic patients could escape the dystrophic phenotype. (c) FRZB gene silencing, through the inhibition exerted on the GSK-3 $\beta$ pool of the Wnt pathway, cannot recover the mTOR pathway. Finally, (d) tideglusib and VP0.7, through efficient inhibition of GSK-3 $\beta$, rescue the Wnt and mTOR pathways in vitro in the myotubes of LGMDR1 patients.

There are no other approaches in progress for this disease and these treatments could help correct some of the deficits observed in patients. Moreover, tideglusib has shown to be a safe compound for chronic treatments in phase 2 trials [62-65]. Accordingly, our study supports that the use of tideglusib or VP0.7 could be postulated as possible and safe therapeutic approach to increase protein synthesis that is reduced in LGMDR1 patients. Thus, this treatment would help to avoid the destruction of the structure of the myofibril and to stop the muscular degeneration that patients who suffer from this rare disease undergo.

\section{Materials and Methods}

\subsection{Muscle Biopsy Samples and Primary Cell Culture}

All participants gave informed consent, using forms approved by the Ethics Committee on the Use of Human Subjects in Research at Donostia University Hospital. Muscle biopsy specimens were obtained from adult and pseudo-asymptomatic (05, 09 and 07-109) patients with LGMDR1, in whom the diagnosis had been confirmed genetically by the identification of both mutations in the calpain 3 gene, and from healthy adult controls. These controls were otherwise healthy individuals that underwent surgery for bone fractures and 
the muscle biopsies were obtained during the surgery (Table 1). The pseudo-asymptomatic patients only showed pathological features in the biopsies. Patient 05: Inflammatory reaction around necrotic and non-necrotic fibers. Inflammation collects at the endomysial site sometimes with perivascular infiltrate without destruction of walls of arterioles and venules. Numerous eosinophilic leucocytes are present. Patient 09: Myositis with local infiltration of eosinophils. Patchy, focal inflammatory cells infiltrate with minor changes in the architecture of fibers without changes in the distribution of the fiber type. Patient 07-109: Myositis with local infiltration of eosinophils. General architecture of fibers is preserved, but focally, fiber destruction and infiltration of eosinophils is observed.

Table 1. Muscle and myoblast samples from healthy controls and LGMDR1 patients.

\begin{tabular}{|c|c|c|c|c|c|c|c|}
\hline \multirow[t]{2}{*}{$\begin{array}{l}\text { Biopsy } \\
\text { Number }\end{array}$} & \multirow[t]{2}{*}{ Status } & \multirow[t]{2}{*}{ Gender } & \multirow{2}{*}{$\begin{array}{l}\text { Sample } \\
\text { (Tissue of } \\
\text { Origin) }\end{array}$} & \multirow[t]{2}{*}{ Age } & \multirow[t]{2}{*}{$\begin{array}{c}\text { Functional } \\
\text { Status }\end{array}$} & \multicolumn{2}{|c|}{ CAPN3 Gene Mutations } \\
\hline & & & & & & Mutation 1 & Mutation 2 \\
\hline \multicolumn{8}{|c|}{ Muscle samples } \\
\hline 27 & Control & Male & Quadriceps & 50 & - & - & - \\
\hline 31 & Control & Male & Quadriceps & 46 & - & - & - \\
\hline 33 & Control & Male & Deltoid & 51 & - & - & - \\
\hline 38 & Control & Male & Quadriceps & 31 & - & - & - \\
\hline 39 & Control & Male & Quadriceps & 41 & - & - & - \\
\hline 42 & Control & Female & Quadriceps & 42 & - & - & - \\
\hline 05 & LGMDR1 & Male & Deltoid & 13 & $\begin{array}{c}\text { Pseudo- } \\
\text { Asymptomatic }\end{array}$ & p.(Arg788SerfsX14) & p.(Arg788SerfsX14) \\
\hline 09 & LGMDR1 & Female & Biceps & 14 & $\begin{array}{c}\text { Pseudo- } \\
\text { Asymptomatic }\end{array}$ & p.(Arg490Trp) & p.(Gly691TrpfsX7) \\
\hline 07-109 & LGMDR1 & Male & * & 10 & $\begin{array}{c}\text { Pseudo- } \\
\text { Asymptomatic }\end{array}$ & p.(Arg698Gly) & p.(Arg748Glu) \\
\hline $36^{* *}$ & LGMDR1 & Male & Quadriceps & 26 & Ambulant & p.(Lys254Glu) & p.(Pro637HisfsX25) \\
\hline B10-61 & LGMDR1 & Female & Quadriceps & 23 & Ambulant & p. $($ Pro22Glnfs*35) & p.(Lys211_Glu323del) \\
\hline B09-26 & LGMDR1 & Female & Quadriceps & 48 & Non-ambulant & p.(Arg489Tyr) & p.(Arg788Ser) \\
\hline $97-114$ & LGMDR1 & Male & Deltoid & 49 & Ambulant & p.(Pro637HisfsX25) & p.(Asp665LeufsX18) \\
\hline $97-168$ & LGMDR1 & Male & $*$ & $*$ & Ambulant & p.(Ser479Gly) & p.(Asp665LeufsX18) \\
\hline $97-169$ & LGMDR1 & Male & Deltoid & 51 & Ambulant & p.(Ser479Gly) & p.(Asp665LeufsX18) \\
\hline \multicolumn{8}{|c|}{ Myoblast and CD56- cells samples } \\
\hline $09-23$ & Control & Male & Triceps & 26 & - & - & - \\
\hline $10-36$ & Control & Male & Biceps & 23 & - & - & - \\
\hline $13-05$ & Control & Male & Quadriceps & 14 & - & - & - \\
\hline $13-07$ & Control & Female & Biceps & 36 & - & - & - \\
\hline $15-12$ & Control & Male & Deltoid & 36 & - & - & - \\
\hline $09-21$ & LGMDR1 & Male & Biceps & 19 & Ambulant & p.(His690ArgfsX9) & p.(His690ArgfsX9) \\
\hline $09-24$ & LGMDR1 & Female & Deltoid & 47 & Non-ambulant & p.(Arg788SerfsX14) & p.(Lys595ValfsX70) \\
\hline $09-25$ & LGMDR1 & Male & Deltoid & 28 & Ambulant & p.(Lys254Glu) & p.(Pro637HisfsX25) \\
\hline $10-39$ & LGMDR1 & Male & Deltoid & 29 & Non-ambulant & p.(Lys254del) & p.(X822Leuext62X) \\
\hline \multicolumn{8}{|c|}{ Skin fibroblasts samples } \\
\hline F-08-19 & Control & Female & Skin & 52 & - & - & - \\
\hline F-08-21 & Control & Male & Skin & 49 & - & - & - \\
\hline F-08-30 & Control & Female & Skin & 31 & - & - & - \\
\hline F-09-26 & LGMDR1 & Female & Skin & 49 & Non-ambulant & p.(Arg489Tyr) & p.(Arg788Ser) \\
\hline F-09-50 & LGMDR1 & Female & Skin & 67 & Non-ambulant & p.(Arg788SerfsX14) & p.(Leu212_Val344delfs *) \\
\hline F-17-28 & LGMDR1 & Male & Skin & 29 & Ambulant & p.(Lys254del) & p.(Arg490Trp) \\
\hline
\end{tabular}

${ }^{*}$ information not available. ${ }^{* *} 36$, also identified as $09-25$ in different blots.

Human proximal muscle biopsies were minced and cultured in a monolayer according to the method described by Askanas [66]. To obtain highly purified myoblasts (CD56+) and CD56- cells, primary cultures were sorted by immunomagnetic selection based on the presence of the early cell surface marker CD56 (separator and reagents from Miltenyi Biotec, Bergisch Gladbach, Germany).

CD56+ cells were seeded at $2500-3000$ cells $/ \mathrm{cm}^{2}$ in culture medium for the myoblast stage. When the myoblasts started to fuse, the medium was replaced by a medium containing $2 \%$ of fetal bovine serum (FBS) (Gibco, Thermo Fisher Scientific, Waltham, 
MA, USA) and without growth factors to obtain myotubes. CD56- cells were seeded in collagen-coated plates.

\subsection{Fibroblast Isolation and Culture}

On collection, skin samples were immersed in RPMI 1640 medium and 2\% penicillin (1000 U/mL)/streptomycin (10,000 $\mu \mathrm{g} / \mu \mathrm{L})$ (Gibco, Thermo Fisher Scientific). Then, skin fragments were placed on a moistened surface with Modified Eagle Medium (MEM) (Gibco, Thermo Fisher Scientific), 13\% Newborn Calf Serum (Gibco, Thermo Fisher Scientific), $0.4 \%$ penicillin/streptomycin and $2 \mathrm{mM}$ L-Glutamine (Sigma-Aldrich, San Luis, MO, USA) and incubated at $37^{\circ} \mathrm{C}$, with $5 \% \mathrm{CO}_{2}$. Subsequently, fibroblasts were cultivated in DMEM, $10 \%$ FBS and $2 \%$ penicillin/streptomycin.

\subsection{RNA Interference Knockdown}

The siRNA for FRZB (s5369) knockdown was purchased from Thermo Fisher Scientific. A scrambled siRNA was used as a negative control (AM4611, Thermo Fisher Scientific). Cells plated at 24,000 cells $/ \mathrm{cm}^{2}$ were transfected with the siRNA at a concentration of $5 \mathrm{nM}$ using RiboCellin transfection reagent (Eurobio, Les Ulis, France) following the manufacturer's instructions. After 8 days of differentiation, human primary myotubes were incubated with the corresponding siRNA and the transfection agent. Finally, the RNA obtained from these cultures was analyzed $48 \mathrm{~h}$ post-transfection by quantitative real-time PCR. Likewise, proteins from these cultures were analyzed $72 \mathrm{~h}$ post-transfection.

\subsection{Administration of GSK-3 $\beta$ Inhibitors}

Tideglusib and VP0.7 were synthetized in or laboratories followed previously described procedures $[27,29]$. Compounds were administered at three different doses $(1.2$, 3.0 and $15.0 \mu \mathrm{M}$ ). $\mathrm{LiCl}$ was purchased from Sigma Aldrich (L7026), San Luis, MO, USA and was administered at a dose of $10 \mathrm{mM}$. The treatments were added to myotubes at differentiation day 8, as well as to skin fibroblasts and CD56- cells. DMSO (Thermo Fisher Scientific, BP-231) was used as a negative control for Tideglusib and VP0.7. After $48 \mathrm{~h}$ of treatment, RNA and proteins were extracted.

\subsection{RNA Extraction from Myoblast/Myotubes and Muscle Biopsies}

RNA extraction from primary myoblast/myotubes was performed with a RNeasy Mini Kit (Qiagen, Hilden, Germany). In the case of the muscle biopsies, which were snap frozen and stored at $-80^{\circ} \mathrm{C}$ until use, total RNA was obtained using an RNA-Plus Kit (QBiogene, Carlsbad, CA, USA).

\subsection{Quantitative Real-Time PCR}

The isolated RNA was reverse-transcribed to first-strand complementary DNA (cDNA) in a final volume of $50 \mu \mathrm{L}$ using a High-Capacity cDNA Reverse Transcription Kit (Applied Biosystems, Thermo Fisher Scientific), according to the manufacturer's instructions. To investigate the levels of expression of the differentially expressed genes (CAPN3, FOS, ITGB1BP2, ANOS1 and GAPDH, Table S1) in these tissues, TaqMan quantitative RT-PCR assays were performed, using the 'CFX384 Real-Time PCR Detection System' (Bio-Rad, Hercules, CA, USA). These genes were selected because they are deregulated in the muscle of LGMDR1 patients and their expression was recovered by means of the silencing of $F R Z B$ gene and the lithium treatment in a previous study [24].

\subsection{Muscle Tissue and Cell Preparation for Western Blot Analysis}

Protein obtention from muscle tissues and cell cultures, as well as the procedure for western blot analysis were performed as previously described elsewhere [24]. The used antibodies are detailed in Table S2. The anti-active- $\beta$-catenin antibody is specific for the active form of $\beta$-catenin, dephosphorylated on Ser37 or Thr41 [67]. 
Some limitations have been found in the detection and quantification of different proteins. Total RPS6 bands could not be detected in muscle and myotubes, even though several trials were carried out. P-p70S6K(T389)/p70S6K could not be represented because available samples did not match to obtain the ratio. When a single sample was available, statistical analysis was not performed.

Supplementary Materials: The following are available online at https:/ /www.mdpi.com/article/10 $.3390 / \mathrm{ijms} 22147367 / \mathrm{s} 1$.

Author Contributions: Investigation, A.R., G.G., L.C.-F., A.V. and A.S.; methodology A.R., A.V. and A.S.; formal analysis, A.R., V.P., A.M., A.V., A.L.d.M. and A.S.; writing-original draft preparation, A.R., A.V., V.P., A.M., A.L.d.M. and A.S.; writing-review and editing, A.R., G.G., L.C.-F., A.V., A.S., V.P., A.M. and A.L.d.M.; conceptualization, A.S.; resources, A.S., A.L.d.M., A.A. and A.M.; supervision, A.S., A.L.d.M., V.P. and A.M.; funding acquisition, A.S. and A.L.d.M. All authors have read and agreed to the published version of the manuscript.

Funding: This work was financed through the grants received from the Health Research Fund (PI16/01325, PI17/01841 and DTS19/00061) of the Spanish Ministry of Economy and Competitiveness and the European Union (ERDF) and it was in part supported by the Center for Networked Biomedical Research on Neurodegenerative Diseases (CIBERNED: CB06/05/1126 to A.R., G.G., A.V., L.C.-F., A.L.d.M. and A.S. and CB18/05/00040 to A.M. and V.P.), Carlos III Health Institute and by GENE (Association of Neuromuscular diseases of Gipuzkoa). A.R. was supported by the predoctoral fellowship given by the department of Education, Universities and Research of the Basque Government (PRE-2016-1-0382).

Institutional Review Board Statement: The study was conducted according to the guidelines of the Declaration of Helsinki, and approved by the Ethics Committee of Donostia University Hospital (protocol code ASP-FRZ-2017-01 and date of approval: 18 July 2017).

Informed Consent Statement: Informed consent was obtained from all subjects involved in the study.

Data Availability Statement: Data are contained within the article and Supplementary Materials.

Acknowledgments: The authors are grateful to the patients and donors.

Conflicts of Interest: The authors declare no conflict of interest.

\section{References}

1. Fardeau, M.; Hillaire, D.; Mignard, C.; Feingold, N.; Feingold, J.; Mignard, D.; de Ubeda, B.; Collin, H.; Tome, F.M.; Richard, I.; et al. Juvenile limb-girdle muscular dystrophy. Clinical, histopathological and genetic data from a small community living in the Reunion Island. Brain 1996, 119, 295-308. [CrossRef] [PubMed]

2. Urtasun, M.; Sáenz, A.; Roudaut, C.; Poza, J.J.; Urtizberea, J.A.; Cobo, A.M.; Richard, I.; García, F.; Bragado, F.; Leturcq, F.; et al. Limb-girdle muscular dystrophy in Guipúzcoa (Basque Country, Spain). Brain 1998, 121, 1735-1747. [CrossRef]

3. Sorimachi, H.; Kinbara, K.; Kimura, S.; Takahashi, M.; Ishiura, S.; Sasagawa, N.; Sorimachi, N.; Shimada, H.; Tagawa, K.; Maruyama, K.; et al. Muscle-specific calpain, p94, responsible for limb girdle muscular dystrophy type 2A, associates with connectin through IS2, a p94-specific sequence. J. Biol. Chem. 1995, 270, 31158-31162. [CrossRef] [PubMed]

4. Kinbara, K.; Sorimachi, H.; Ishiura, S.; Suzuki, K. Skeletal muscle-specific calpain, p49: Structure and physiological function. Biochem. Pharmacol. 1998, 56, 415-420. [CrossRef]

5. García Díaz, B.E.; Gauthier, S.; Davies, P.L. Ca2+ dependency of calpain 3 (p94) activation. Biochemistry 2006, 45, 3714-3722. [CrossRef]

6. Ono, Y.; Torii, F.; Ojima, K.; Doi, N.; Yoshioka, K.; Kawabata, Y.; LAbeit, D.; Labeit, S.; Suzuki, K.; Abe, K.; et al. Suppressed disassembly of autolyzing p94/CAPN3 by N2A connectin/titin in a genetic reporter system. J. Biol. Chem. 2006, 281, 18519-18531. [CrossRef]

7. Hayashi, C.; Ono, Y.; Doi, N.; Kitamura, F.; Tagami, M.; Mineki, R.; Arai, T.; Taguchi, H.; Yanagida, M.; Hirner, S.; et al. Multiple molecular interactions implicate the connectin/titin N2A region as a modulating scaffold for p94/calpain 3 activity in skeletal muscle. J. Biol. Chem. 2008, 283, 14801-14814. [CrossRef]

8. Huang, Y.; Verheesen, P.; Roussis, A.; Frankhuizen, W.; Ginjaar, I.; Haldane, F.; Laval, S.; Anderson, L.V.B.; Verrips, T.; Frants, R.R.; et al. Protein studies in dysferlinopathy patients using llama-derived antibody fragments selected by phage display. Eur. J. Hum. Genet. 2005, 13, 721-730. [CrossRef] [PubMed]

9. Huang, Y.; de Morrée, A.; van Remoortere, A.; Bushby, K.; Frants, R.R.; den Dunnen, J.T.; van der Maarel, S.M. Calpain 3 is a modulator of the dysferlin protein complex in skeletal muscle. Hum. Mol. Genet. 2008, 17, 1855-1866. [CrossRef] 
10. Toral-Ojeda, I.; Aldanondo, G.; Lasa-Elgarresta, J.; Lasa-Fernández, H.; Fernández-Torrón, R.; de Munain, A.L.; VallejoIllarramendi, A. Calpain 3 deficiency affects SERCA expression and function in the skeletal muscle. Expert Rev. Mol. Med. 2016, 18, e7. [CrossRef] [PubMed]

11. Scicchitano, B.M.; Dobrowolny, G.; Sica, G.; Musarò, A. Molecular Insights into Muscle Homeostasis, Atrophy and Wasting. Curr. Genom. 2018, 19, 356-369. [CrossRef] [PubMed]

12. Glass, D.J. Skeletal muscle hypertrophy and atrophy signaling pathways. Int. J. Biochem. Cell. Biol. 2005, 37, 1974-1984. [CrossRef] [PubMed]

13. von Maltzahn, J.; Chang, N.C.; Bentzinger, C.F.; Rudnicki, M.A. Wnt signaling in myogenesis. Trends Cell Biol. 2012, 22, 602-609. [CrossRef] [PubMed]

14. Behrens, J.; von Kries, J.P.; Kühl, M.; Bruhn, L.; Wedlich, D.; Grosschedl, R.; Birchmeier, W. Functional interaction of be-ta-catenin with the transcription factor LEF-1. Nature 1996, 382, 638-642. [CrossRef] [PubMed]

15. Clevers, H.; van de Wetering, M. TCF/LEF factor earn their wings. Trends Genet. 1997, 13, 485-489. [CrossRef]

16. MacDonald, B.T.; Tamai, K.; He, X. Wnt/beta-catenin signaling: Components, mechanisms, and diseases. Dev. Cell. 2009, 17, 9-26. [CrossRef] [PubMed]

17. Beurel, E.; Grieco, S.F.; Jope, R.S. Glycogen synthase kinase-3 (GSK3): Regulation, actions, and diseases. Pharmacol. Ther. 2015, 148, 114-131. [CrossRef]

18. Doble, B.W.; Woodgett, J.R. GSK-3: Tricks of the trade for a multi-tasking kinase. J. Cell Sci. 2003, 116, 1175-1186. [CrossRef] [PubMed]

19. Cormier, K.W.; Woodgett, J.R. Recent advances in understanding the cellular roles of GSK-3. F1000Research 2017, 6, F1000. [CrossRef]

20. Sutherland, C. What Are the bona fide GSK3 Substrates? Int. J. Alzheimers Dis. 2011, 2011, 505607. [CrossRef]

21. Du, W.J.; Li, J.K.; Wang, Q.Y.; Hou, J.B.; Yu, B. Lithium chloride preconditioning optimizes skeletal myoblast functions for cellular cardiomyoplasty in vitro via glycogen synthase kinase-3beta/beta-catenin signaling. Cells Tissues Organs 2009, 190, 11-19. [CrossRef]

22. Yang, Y.; Yang, J.; Liu, R.; Li, H.; Luo, X.; Yang, G. Accumulation of $\beta$-catenin by lithium chloride in porcine myoblast cultures accelerates cell differentiation. Mol. Biol. Rep. 2011, 38, 2043-2049. [CrossRef] [PubMed]

23. Abu-Baker, A.; Laganiere, J.; Gaudet, R.; Rochefort, D.; Brais, B.; Neri, C.; Dion, P.A.; Rouleau, G.A. Lithium chloride attenuates cell death in oculopharyngeal muscular dystrophy by perturbing Wnt/ $\beta$-catenin pathway. Cell Death. Dis. 2013, 4, e821. [CrossRef] [PubMed]

24. Jaka, O.; Casas-Fraile, L.; Azpitarte, M.; Aiastui, A.; López de Munain, A.; Sáenz, A. FRZB and melusin, overexpressed in LGMD2A, regulate integrin $\beta 1 \mathrm{D}$ isoform replacement altering myoblast fusion and the integrin-signalling pathway. Expert Rev. Mol. Med. 2017, 19, e2. [CrossRef] [PubMed]

25. Biagioni, F.; Ferrucci, M.; Ryskalin, L.; Fulceri, F.; Lazzeri, G.; Calierno, M.T.; Busceti, C.L.; Ruffoli, R.; Fornai, F. Protective effects of long-term lithium administration in a slowly progressive SMA mouse model. Arch. Ital. Biol. 2017, 155, 118-130. [CrossRef] [PubMed]

26. Findlay, A.R.; Bengoechea, R.; Pittman, S.K.; Chou, T.F.; True, H.L.; Weihl, C.C. Lithium chloride corrects weakness and myopathology in a preclinical model of LGMD1D. Neurol. Genet. 2019, 5, e318. [CrossRef]

27. Palomo, V.; Perez, D.I.; Roca, C.; Anderson, C.; Rodríguez-Muela, N.; Perez, C.; Morales-Garcia, J.A.; Reyes, J.A.; Campillo, N.E.; Perez-Castillo, A.M.; et al. Subtly Modulating Glycogen Synthase Kinase $3 \beta$ : Allosteric Inhibitor Development and Their Potential for the Treatment of Chronic Diseases. J. Med. Chem. 2017, 60, 4983-5001. [CrossRef]

28. Eldar-Finkelman, H.; Licht-Murava, A.; Pietrokovski, S.; Eisenstein, M. Substrate competitive GSK-3 inhibitors-strategy and implications. Biochim. Biophys. Acta 2010, 1804, 598-603. [CrossRef] [PubMed]

29. Martinez, A.; Alonso, M.; Castro, A.; Pérez, C.; Moreno, F.J. First non-ATP competitive glycogen synthase kinase 3 beta (GSK3beta) inhibitors: Thiadiazolidinones (TDZD) as potential drugs for the treatment of Alzheimer's disease. J. Med. Chem. 2002, 45, 1292-1299. [CrossRef]

30. Palomo, V.; Soteras, I.; Perez, D.I.; Perez, C.; Gil, C.; Campillo, N.E.; Martinez, A. Exploring the binding sites of glycogen synthase kinase 3. Identification and characterization of allosteric modulation cavities. J. Med. Chem. 2011, 54, 8461-8470. [CrossRef] [PubMed]

31. Lovestone, S.; Boada, M.; Dubois, B.; Hull, M.; Rinne, J.; Huppertz, H.J.; Calero, M.; Andrés, M.; Gómez-Carrillo, B.; León, T.; et al. A phase II trial of tideglusib in Alzheimer's disease. J. Alzheimers Dis. 2015, 45, 75-88. [CrossRef]

32. Kramerova, I.; Kudryashova, E.; Tidball, J.G.; Spencer, M.J. Null mutation of calpain 3 (p94) in mice causes abnormal sarcomere formation in vivo and in vitro. Hum. Mol. Genet. 2004, 13, 1373-1388. [CrossRef]

33. Sáenz, A.; Azpitarte, M.; Armañanzas, R.; Leturcq, F.; Alzualde, A.; Inza, I.; García-Bragado, F.; De la Herran, G.; Corcuera, J.; Cabello, A.; et al. Gene expression profiling in limb-girdle muscular dystrophy 2A. PLoS ONE 2008, 3, e3750. [CrossRef] [PubMed]

34. Pardo, J.V.; Siliciano, J.D.; Craig, S.W. A vinculin-containing cortical lattice in skeletal muscle: Transverse lattice elements ("costameres") mark sites of attachment between myofibrils and sarcolemma. Proc. Natl. Acad. Sci. USA 1983, 80, 1008-1012. [CrossRef] 
35. Danowski, B.A.; Imanaka-Yoshida, K.; Sanger, J.M.; Sanger, J.W. Costameres are sites of force transmission to the substratum in adult rat cardiomyocytes. J. Cell Biol. 1992, 118, 1411-1420. [CrossRef] [PubMed]

36. Trimarchi, F.; Favaloro, A.; Fulle, S.; Magaudda, L.; Puglielli, C.; Di Mauro, D. Culture of human skeletal muscle myoblasts: Timing appearance and localization of dystrophin-glycoprotein complex and vinculin-talin-integrin complex. Cells Tissues Organs 2006, 183, 87-98. [CrossRef]

37. Legate, K.R.; Wickström, S.A.; Fässler, R. Genetic and cell biological analysis of integrin outside-in signaling. Genes Dev. 2009, 23, 397-418. [CrossRef] [PubMed]

38. Burke, G.; Hillier, C.; Cole, J.; Sampson, M.; Bridges, L.; Bushby, K.; Barresi, R.; Hammans, S.R. Calpainopathy presenting as foot drop in a 41 year old. Neuromuscul. Disord. 2010, 20, 407-410. [CrossRef] [PubMed]

39. Pullen, N.; Thomas, G. The modular phosphorylation and activation of p70s6k. FEBS Lett. 1997, 410, 78-82. [CrossRef]

40. Fenton, T.R.; Gout, I.T. Functions and regulation of the 70kDa ribosomal S6 kinases. Int. J. Biochem. Cell Biol. 2011, 43, 47-59. [CrossRef]

41. Moorwood, C.; Philippou, A.; Spinazzola, J.; Keyser, B.; Macarak, E.J.; Barton, E.R. Absence of $\gamma$-sarcoglycan alters the response of p70S6 kinase to mechanical perturbation in murine skeletal muscle. Skelet Muscle 2014, 4, 13. [CrossRef]

42. Nielsen, P.J.; Manchester, K.L.; Towbin, H.; Gordon, J.; Thomas, G. The phosphorylation of ribosomal protein S6 in rat tissues following cycloheximide injection, in diabetes, and after denervation of diaphragm. A simple immunological determination of the extent of S6 phosphorylation on protein blots. J. Biol. Chem. 1982, 257, 12316-12321. [CrossRef]

43. Du, J.; Guan, T.; Zhang, H.; Xia, Y.; Liu, F.; Zhang, Y. Inhibitory crosstalk between ERK and AMPK in the growth and proliferation of cardiac fibroblasts. Biochem. Biophys. Res. Commun. 2008, 368, 402-407. [CrossRef] [PubMed]

44. Hwang, S.L.; Jeong, Y.T.; Li, X.; Kim, Y.D.; Lu, Y.; Chang, Y.C.; Lee, I.C.; Chang, H.W. Inhibitory cross-talk between the AMPK and ERK pathways mediates endoplasmic reticulum stress-induced insulin resistance in skeletal muscle. Br. J. Pharmacol. 2013, 169, 69-81. [CrossRef] [PubMed]

45. Bautista, S.J.; Boras, I.; Vissa, A.; Mecica, N.; Yip, C.M.; Kim, P.K.; Antonescu, C.N. mTOR complex 1 controls the nuclear localization and function of glycogen synthase kinase 3ß. J. Biol. Chem. 2018, 293, 14723-14739. [CrossRef] [PubMed]

46. Casas-Fraile, L.; Cornelis, F.M.; Costamagna, D.; Rico, A.; Duelen, R.; Sampaolesi, M.M.; de Munain, A.L.; Lories, R.J.; Sáenz, A. Frizzled related protein deficiency impairs muscle strength, gait and calpain 3 levels. Orphanet. J. Rare Dis. 2020, 15, 119. [CrossRef] [PubMed]

47. Bhatnagar, S.; Kumar, A. Therapeutic targeting of signaling pathways in muscular dystrophy. J. Mol. Med. 2010, 88, 155-166. [CrossRef]

48. Baghdiguian, S.; Martin, M.; Richard, I.; Pons, F.; Astier, C.; Bourg, N.; Hay, R.T.; Chemaly, R.; Halaby, G.; Loiselet, J.; et al. Calpain 3 deficiency is associated with myonuclear apoptosis and profound perturbation of the IkappaB alpha/NF-kappaB pathway in limb-girdle muscular dystrophy type 2A. Nat. Med. 1999, 5, 503-511. [CrossRef]

49. Yalvac, M.E.; Amornvit, J.; Braganza, C.; Chen, L.; Hussain, A.; Shontz, K.M.; Montgomery, C.L.; Flanigan, K.M.; Lewis, S.; Sahenk, Z. Impaired regeneration in calpain-3 null muscle is associated with perturbations in mTORC1 signaling and defective mitochondrial biogenesis. Skelet Muscle 2017, 7, 27. [CrossRef]

50. Fingar, D.C.; Blenis, J. Target of rapamycin (TOR): An integrator of nutrient and growth factor signals and coordinator of cell growth and cell cycle progression. Oncogene 2004, 23, 3151-3171. [CrossRef]

51. Hay, N.; Sonenberg, N. Upstream and downstream of mTOR. Genes Dev. 2004, 18, 1926-1945. [CrossRef] [PubMed]

52. Wullschleger, S.; Loewith, R.; Hall, M.N. TOR signaling in growth and metabolism. Cell 2006, 124, 471-484. [CrossRef] [PubMed]

53. Inoki, K.; Ouyang, H.; Zhu, T.; Lindvall, C.; Wang, Y.; Zhang, X.; Yang, Q.; Bennett, C.; Harada, Y.; Stankunas, K.; et al. TSC2 integrates Wnt and energy signals via a coordinated phosphorylation by AMPK and GSK3 to regulate cell growth. Cell 2006, 126, 955-968. [CrossRef] [PubMed]

54. Zhai, P.; Sciarretta, S.; Galeotti, J.; Volpe, M.; Sadoshima, J. Differential roles of GSK-3 $\beta$ during myocardial ischemia and ischemia/reperfusion. Circ. Res. 2011, 109, 502-511. [CrossRef] [PubMed]

55. Kahn, B.B.; Alquier, T.; Carling, D.; Hardie, D.G. AMP-activated protein kinase: Ancient energy gauge provides clues to modern understanding of metabolism. Cell Metab. 2005, 1, 15-25. [CrossRef]

56. Inoki, K.; Zhu, T.; Guan, K.L. TSC2 mediates cellular energy response to control cell growth and survival. Cell 2003, 115, 577-590. [CrossRef]

57. Rosso, P.; Fioramonti, M.; Fracassi, A.; Marangoni, M.; Taglietti, V.; Siteni, S.; Segatto, M. AMPK in the central nervous system: Physiological roles and pathological implications. Res. Rep. Biol. 2016, 7, 1-13. [CrossRef]

58. Ding, V.W.; Chen, R.H.; McCormick, F. Differential regulation of glycogen synthase kinase 3beta by insulin and Wnt signaling. J. Biol. Chem. 2000, 275, 32475-32481. [CrossRef]

59. Schaefer, K.N.; Peifer, M. Wnt/Beta-Catenin Signaling Regulation and a Role for Biomolecular Condensates. Dev. Cell. 2019, 48, 429-444. [CrossRef]

60. Beurel, E.; Kaidanovich-Beilin, O.; Yeh, W.I.; Song, L.; Palomo, V.; Michalek, S.M.; Woodgett, J.R.; Harrington, L.E.; EldarFinkelman, H.; Martinez, A.; et al. Regulation of Th1 cells and experimental autoimmune encephalomyelitis by glycogen synthase kinase-3. J. Immunol. 2013, 190, 5000-5011. [CrossRef] 
61. Morales-García, J.A.; Susín, C.; Alonso-Gil, S.; Pérez, D.I.; Palomo, V.; Pérez, C.; Conde, S.; Santos, A.; Gil, C.; Martínez, A.; et al. Glycogen synthase kinase-3 inhibitors as potent therapeutic agents for the treatment of Parkinson disease. ACS Chem. Neurosci. 2013, 4, 350-360. [CrossRef] [PubMed]

62. del Ser, T.; Steinwachs, K.C.; Gertz, H.J.; Andrés, M.V.; Gómez-Carrillo, B.; Medina, M.; Vericat, J.A.; Redondo, P.; Fleet, D.; León, T. Treatment of Alzheimer's disease with the GSK-3 inhibitor tideglusib: A pilot study. J. Alzheimers Dis. 2013, 33, 205-215. [CrossRef] [PubMed]

63. Tolosa, E.; Litvan, I.; Höglinger, G.U.; Burn, D.; Lees, A.; Andrés, M.V.; Gómez-Carrillo, B.; León, T.; Del Ser, T.; TAUROS Investigators. A phase 2 trial of the GSK-3 inhibitor tideglusib in progressive supranuclear palsy. Mov Disord. 2014, $29,470-478$. [CrossRef]

64. Palomo, V.; Martinez, A. Glycogen synthase kinase 3 (GSK-3) inhibitors: A patent update (2014-2015). Expert Opin. Ther. Pat. 2017, 27, 657-666. [CrossRef]

65. Horrigan, J.; Gomes, T.B.; Snape, M.; Nikolenko, N.; McMorn, A.; Evans, S.; Yaroshinsky, A.; Pasqua, O.D.; Oosterholt, S.; Lochmüller, H. A Phase 2 Study of AMO-02 (Tideglusib) in Congenital and Childhood-Onset Myotonic Dystrophy Type 1 (DM1). Pediatr. Neurol. 2020, 112, 84-93. [CrossRef]

66. Askanas, V.; Engel, W.K. A new program for investigating adult human skeletal muscle grown aneurally in tissue culture. Neurology 1975, 25, 58-67. [CrossRef] [PubMed]

67. van Noort, M.; Meeldijk, J.; van der Zee, R.; Destree, O.; Clevers, H. Wnt signaling controls the phosphorylation status of beta-catenin. J. Biol. Chem. 2002, 277, 17901-17905. [CrossRef] 